\title{
Effects of temperature on herpes-like virus detection among hatchery-reared larval Pacific oyster Crassostrea gigas
}

\author{
R. M. Le Deuff ${ }^{1}$, T. Renault ${ }^{1, *}$, A. Gérard ${ }^{2}$ \\ ${ }^{1}$ Unité de Recherche en Pathologie et Immunologie Générales, ${ }^{2}$ Unité de Recherche en Génétìque et Ecloserie; \\ Laboratoire de Génétique, Aquaculture et Pathologie, IFREMER, BP 133, F-17390 La Tremblade, France
}

\begin{abstract}
This paper describes effects of temperature on herpes-like virus detection in Pacific oyster Crassostrea gigas larvae held at different temperatures. Intranuclear, intracytoplasmic and extracellular viral particles were observed in velum and mantle connective tissues of oyster larvae reared at $25-26^{\circ} \mathrm{C}$. In larvae held at $22-23^{\circ} \mathrm{C}$, although nuclear lesions were observed, the presence of viral particles was not detected. Results were obtained for oyster larvae with 4 different parental origins. Herpesvirus infection was found in 3 of the 4 groups of oyster larvae held in the same conditions at the higher temperature.
\end{abstract}

KEY WORDS: Herpesvirus · Pacific oyster $\cdot$ Crassostrea gigas $\cdot$ Larval culture $\cdot$ Mortality $\cdot$ Temperature

\section{INTRODUCTION}

The Pacific oyster Crassostrea gigas is the most important species of mollusc reared in the world (FAO 1989) and is of particular importance for French mariculture. However, cultivation may be endangered by the occurrence of epizootics, especially viral diseases, which are considered one of the major risks to production. Indeed, oyster mortalities were described and associated with the presence of several families of morphologically described viruses among different species of ostreids. The first was reported in adult American oysters Crassostrea virginica and described as a member of the family Herpesviridae (Farley 1972). More remarkably, mass mortalities of adult Portuguese oyster Crassostrea angulata among French livestock were caused by an iridovirus between 1967 and 1970 (Comps \& Duthoit 1976, Comps et al. 1976, Comps \& Bonami 1977). Other important viruses described from ostreids are members of the families Iridoviridae, Papovaviridae, Togaviridae, Retroviridae and Reo-

•E-mail: trenault@ifremer.fr viridae (Elston 1979, Elston \& Wilkinson 1985, Farley 1976, 1978, Meyers 1979).

More recently, in 1991, other viruses belonging to the Herpesviridae were associated with high mortalities of hatchery-reared larvae of Crassostrea gigas in France (Nicolas et al. 1992) and in New Zealand (Hine et al. 1992). Subsequently, sporadic high mortalities of larval C. gigas were observed in 1992, 1993 and 1994 associated with a herpes-like virus in some French hatcheries (Renault et al. 1994b). The pathogenicity of this virus was demonstrated earlier by experimental transmission of the disease to axenic C. gigas larvae (Le Deuff et al. 1994). Additionally, mortalities of oyster spat of Ostrea edulis and C. gigas were also associated with herpes-like viruses (Comps \& Cochennec 1993, Renault et al. 1994a). These herpes-associated mortalities among ostreids all occurred during hotter summer periods. Thus, it appeared necessary to investigate the effects of temperature on the induction of these viral infections. For this purpose, we cultured $C$. gigas larvae at high $\left(25-26^{\circ} \mathrm{C}\right)$ and low $\left(22-23^{\circ} \mathrm{C}\right)$ temperatures and we examined the susceptibility to the disease of larvae from broodstocks of different geographical origins. 


\section{MATERIAL AND METHODS}

Specimens. Pacific oyster Crassostrea gigas broodstocks originated from 4 different French locations (Marennes, La Tremblade, Brest and Arcachon) indicated in Fig. 1. Oysters from La Tremblade originated from Arcachon, but were transferred and kept in the hatchery at La Tremblade for 12 mo before the experiments. Oysters from Marennes (Charente-Maritime), La Tremblade (Charente-Maritime) and Brest (Brittany) were conditioned at the IFREMER laboratory at 20 to $22^{\circ} \mathrm{C}$ for $3 \mathrm{wk}$ in order to improve gamete quality before spawning. Cultured oysters from Arcachon (Gironde) were used for spawns directly after being caught, without the step of conditioning in the hatchery.

Spawns and larval cultures. Gametes were rernvered by strip dissection of gonads. Fertilization was performed with males and females of the same geographic origin. These respective spawns were divided in 2 groups held either at $22-23$ or at $25-26^{\circ} \mathrm{C}$, for $15 \mathrm{~d}$. Survival rates were estimated by counting oyster larvae in a Sedgewick-Rafter counting cell S50. Dead larvae were differentiated from healthy and moribund larvae on the basis of swimming activity. For each culture, 30 larvae were measured with a micrometer and the average size calculated. Samples of larvae were fixed for transmission electron microcopy as described below.

Transmission electron microscopy. Samples of larvae were fixed $\left(1 \mathrm{~h}, 4^{\circ} \mathrm{C}\right)$ in $3 \%$ glutaraldehyde in $0.2 \mathrm{M}$ cacodylate buffer ( $\mathrm{pH} 7.2)$, post-fixed $\left(1 \mathrm{~h}, 4^{\circ} \mathrm{C}\right.$ ) with $1 \%$ osmium tetroxide in the same buffer, dehydrated through an ascending ethanol series $\left(70^{\circ}, 95^{\circ}\right.$ and $100^{\circ}$ ), partially rehydrated by two $10 \mathrm{~min}$ baths of cacodylate buffer and decalcified overnight with $2 \%$ EDTA in cacodylate buffer. After a second dehydration, samples were cleared with propylene oxide and embedded in Epon resin. Thick sections (1 $\mu \mathrm{m})$ for light microscopy were stained in $0.5 \%$ toluidine blue

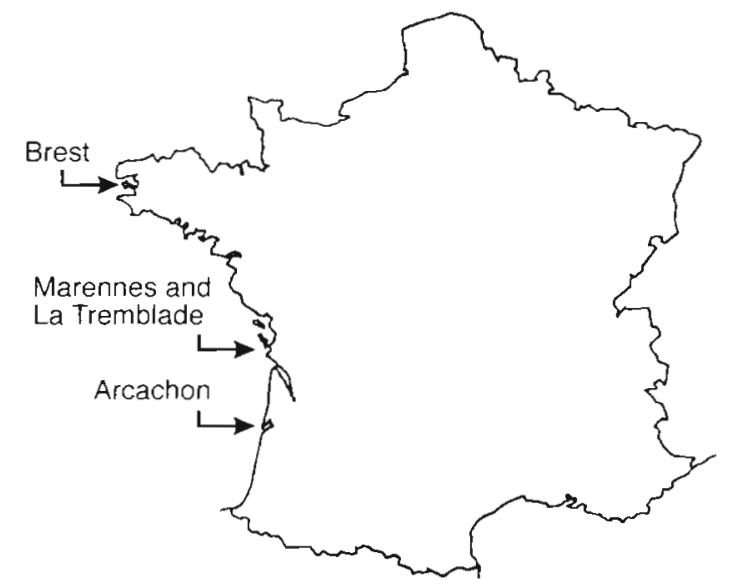

Fig. 1. Origin of cultured Pacific oyster broodstocks in France in $1 \%$ aqueous sodium borate solution. Ultrathin sections were collected on copper grids and stained with uranyl acetate and lead citrate. These sections were then examined with a JEOL JEM 1200EX transmission electron microscope at $60 \mathrm{kV}$.

\section{RESULTS}

\section{Larval mortalities and growth rates}

Dead larvae were differentiated from healthy (swimming actively) and moribund (swimming slowly in circles) larvae. Moreover, rounded cells and portions of velum could be seen detaching from dead larvae. Survival rates of the different larval cultures are shown in Fig. 2. Different results were obtained for groups
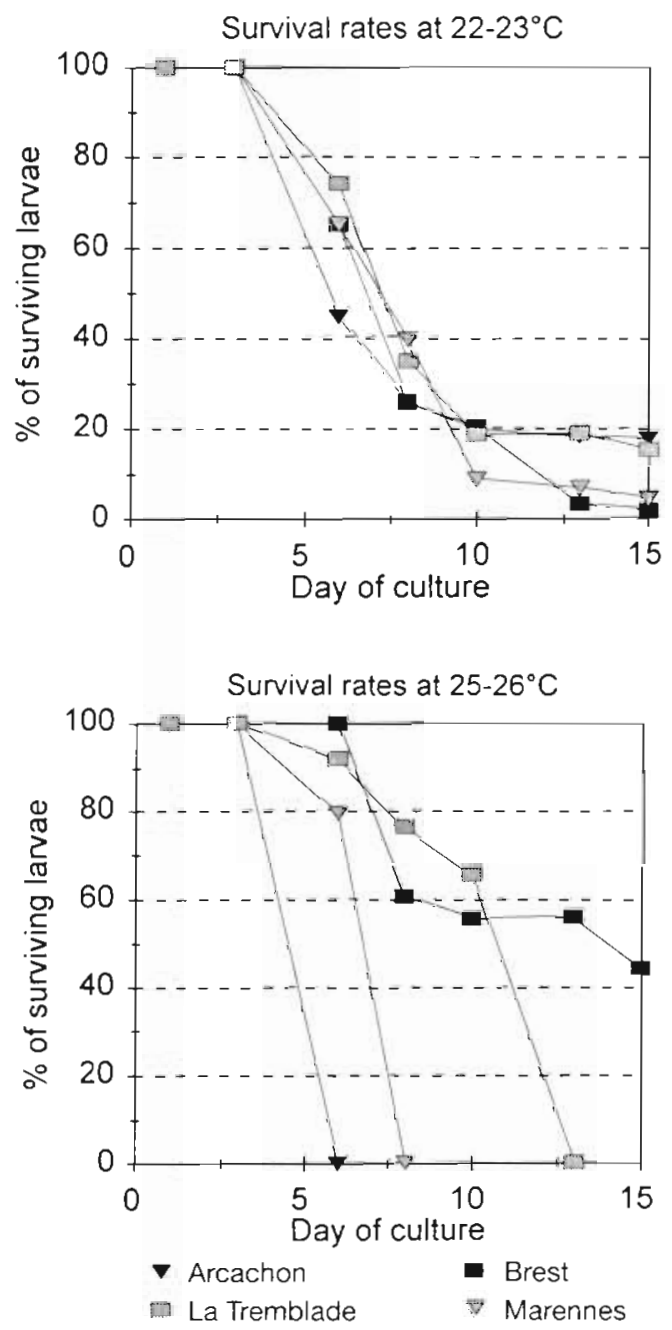

Fig. 2. Crassostrea gigas. Survival rates of Pacific oyster larvae held at either $22-23^{\circ} \mathrm{C}$ or $25-26^{\circ} \mathrm{C}$. Spawns were performed with broodstocks from 4 different French sites: Arcachon, La Tremblade, Brest and Marennes 
of larvae reared under exactly the same conditions. At $25-26^{\circ} \mathrm{C}$, mortalities of oyster larvae from Arcachon, Marennes and La Tremblade started on Day 4 post fertilization. Survival rates at $25-26^{\circ} \mathrm{C}$ decreased suddenly and reached $0 \%$ on Day 6 for oyster larvae from Arcachon, on Day 8 for larvae from Marennes and on Day 13 for larvae from La Tremblade. In contrast, good survival rates on Day 15 of culture $(44.4 \%)$ were observed for larvae from Brest.

Mortality rates in groups of oyster larvae cultured at $22-23^{\circ} \mathrm{C}$ were more progressive and, for larvae from Arcachon, Marennes and La Tremblade, lower than in the corresponding $25-26^{\circ} \mathrm{C}$ groups. On Day 15 post fertilization, survival rates were $1.6 \%$ for oyster larvae from Arcachon, $14.8 \%$ for larvae from Marennes, $4.2 \%$ for larvae from La Tremblade and $17.4 \%$ for larvae from Brest.

Growth rates did not show significant differences between groups of larvae held at the same temperatures (Fig. 3). High mortalities occurred on some groups of larvae held at $25-26^{\circ} \mathrm{C}$ between Days 4 and 11 , when these larvae had an average size of 95 to $162 \mu \mathrm{m}$. On Days 1 to 11 of culture, growth rates for groups of larvae reared at $25-26^{\circ} \mathrm{C}$ were higher than for those reared at $22-23^{\circ} \mathrm{C}$. However, average larval length reached similar values on Day 15 of culture. Indeed, larvae from Brest held at $25-26^{\circ} \mathrm{C}$ measured $230 \mu \mathrm{m}$, while larvae from the different groups held at $22-23^{\circ} \mathrm{C}$ measured 220 to $255 \mu \mathrm{m}$.

\section{Histological and transmission electron microscope analysis}

Analysis of semithin sections under light microscopy (Table 1) revealed nuclear alterations in oyster larvae from Arcachon, Marennes and La Tremblade cultivated at $22-23^{\circ} \mathrm{C}$ and $25-26^{\circ} \mathrm{C}$. No lesions were observed in either group of oyster larvae from Brest. These alterations included condensed nuclei and nuclei presenting marginated chromatin (Fig. 4).

Analysis by transmission electron microscopy (Table 1) revealed the presence of herpes-like viral particles (Figs. 5 to 9) only in samples of oyster larvae from Arcachon, Marennes and La Tremblade held at higher temperatures $\left(25-26^{\circ} \mathrm{C}\right)$. Under transmission electron microscopy, interstitial and epithelial cells of the velum exhibited intranuclear and intracytoplasmic virus-like particles. In infected cells, the nucleus contained spherical or polygonal particles $80 \mathrm{~nm}$ in diameter. Some particles appeared empty and consisted of structures assumed to be capsids, others contained an electrondense core and were interpreted as being nucleocapsids (Figs. 5 \& 6). Enveloped single virions were observed in the cytoplasm (Fig. 7) and in extracellular spaces (Fig. 8).
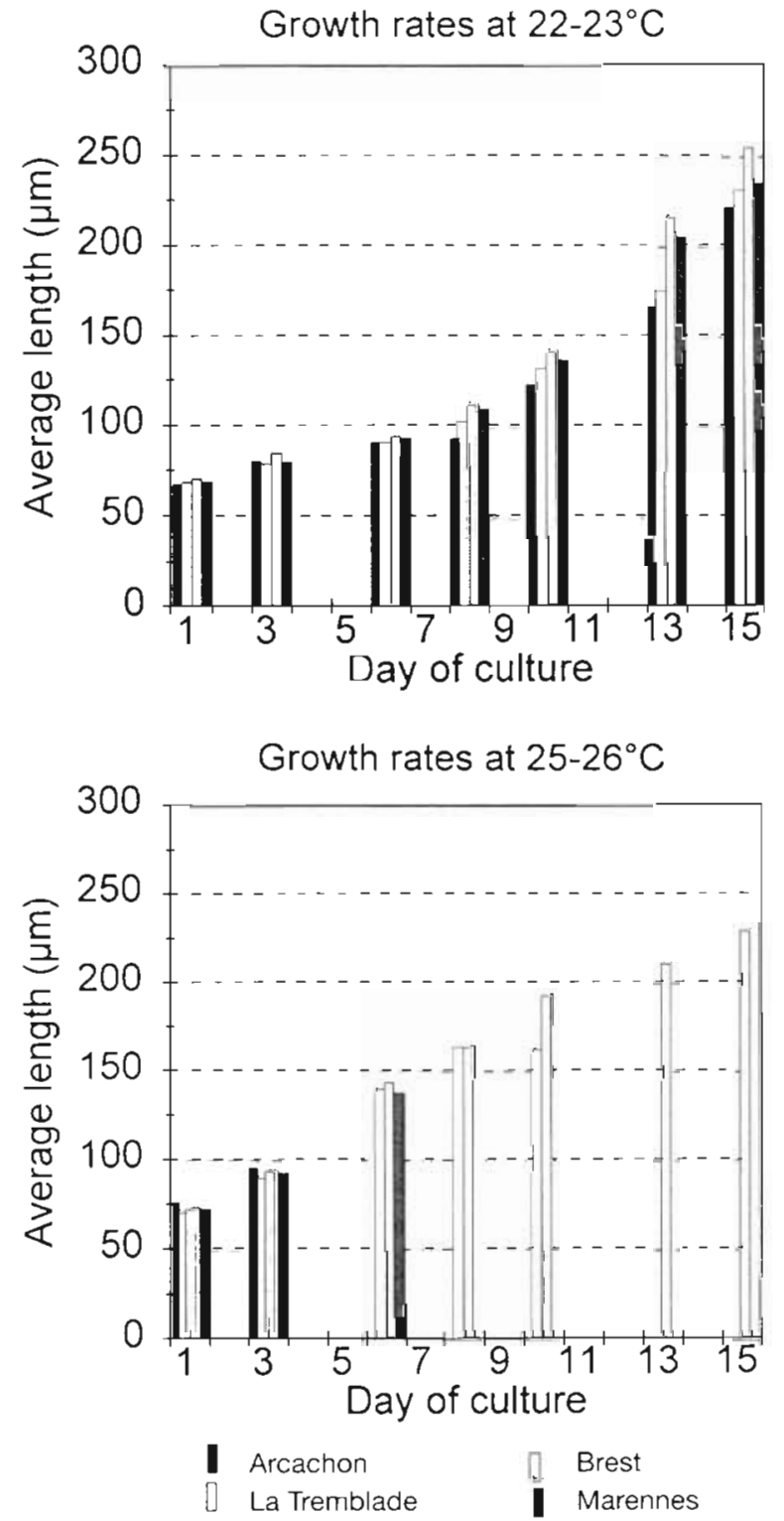

Fig. 3. Crassostrea gigas. Growth rates of Pacific oyster larvae held at either $22-23^{\circ} \mathrm{C}$ or $25-26^{\circ} \mathrm{C}$. Larvae were obtained from broodstocks originating in Arcachon, La Tremblade Brest and Marennes

These particles consisted of a capsid with an electrondense core that was in turn surrounded by an envelope with a typical membrane-like trilaminar appearance. In oyster larvae cultivated at $25-26^{\circ} \mathrm{C}$, viral particles were first detected on Day 6 post fertilization for oysters from Marennes and Arcachon, and on Day 8 for oysters from La Tremblade. Good survival rates were obtained in larvae of parents originating from Brest, and herpes-like virus was not detected in these larvae reared at either $22-23^{\circ} \mathrm{C}$ or $25-26^{\circ} \mathrm{C}$.

Moreover, herpes-like viral particles were not detected in any larvae reared at $22-23^{\circ} \mathrm{C}$. However, some 
Table 1 Crassostrea gigas. Transmission electron microscope and light microscope examination of fixed samples of Pacific oyster larvae held at different temperatures, $22-23$ (22) or $25-26^{\circ} \mathrm{C}(25)$. Observation of nuclear alterations (NA) and/or the presence of herpes-like viral particles (VP) are indicated as a percentage calculated from the indicated number of oyster larvae examined in each case $(\mathrm{N})$. nd: not determined - -: $100 \%$ mortality occurred, no analysis was performed later

\begin{tabular}{|c|c|c|c|c|c|c|c|c|c|c|}
\hline & \multicolumn{4}{|c|}{ Light microscopy } & \multicolumn{6}{|c|}{ Transmission electron microscopy } \\
\hline & \multicolumn{2}{|c|}{ NA } & \multicolumn{2}{|c|}{$\mathrm{N}$} & \multicolumn{2}{|c|}{ NA } & \multicolumn{2}{|c|}{ VP } & \multicolumn{2}{|c|}{$N$} \\
\hline & 22 & 25 & 22 & 25 & 22 & 25 & 22 & 25 & 22 & 25 \\
\hline \multicolumn{11}{|c|}{ Arcachon } \\
\hline Day 6 & $0 \%$ & $100 \%$ & 100 & 50 & $0 \%$ & $100 \%$ & $0 \%$ & $100 \%$ & 6 & 4 \\
\hline Day 8 & $0 \%$ & - & 70 & - & $0 \%$ & - & $0 \%$ & - & 10 & - \\
\hline Day 10 & $10 \%$ & - & 40 & - & $8 \%$ & - & $0 \%$ & - & 12 & - \\
\hline Day 13 & $25 \%$ & - & 32 & - & $0 \%$ & - & $0 \%$ & - & 6 & - \\
\hline Day 15 & & - & & - & & - & & - & & - \\
\hline \multicolumn{11}{|c|}{ La Tremblade } \\
\hline Day 6 & $0 \%$ & $0 \%$ & 90 & 60 & $0 \%$ & $0 \%$ & $0 \%$ & $0 \%$ & 6 & 4 \\
\hline Day 8 & $0 \%$ & $49 \%$ & 95 & 45 & $0 \%$ & $100 \%$ & $0 \%$ & $100 \%$ & 9 & 4 \\
\hline Day 10 & nd & & nd & & $8 \%$ & & $0 \%$ & & 6 & \\
\hline Day 13 & $3 \%$ & $100^{\circ}$ & 35 & $45^{a}$ & $0 \%$ & b & $0 \%$ & b & 2 & 4 \\
\hline Day 15 & $10.5 \%$ & - & 19 & - & $0 \%$ & - & $0 \%$ & - & 2 & - \\
\hline \multicolumn{11}{|l|}{ Brest } \\
\hline Day 6 & $0 \%$ & \multirow{4}{*}{$0 \%$} & 90 & \multirow{4}{*}{70} & $0 \%$ & \multirow{4}{*}{$0 \%$} & $0 \%$ & \multirow{4}{*}{$0 \%$} & 5 & \multirow{4}{*}{3} \\
\hline Day 8 & & & & & & & & & & \\
\hline Day 10 & $0 \%$ & & 35 & & $0 \%$ & & $0 \%$ & & 5 & \\
\hline Day 13 & & & & & & & & & & \\
\hline Day 15 & $0 \%$ & $0 \%$ & 22 & 31 & $0 \%$ & $0 \%$ & $0 \%$ & $0 \%$ & 5 & 4 \\
\hline \multicolumn{11}{|c|}{ Marennes } \\
\hline Day 6 & $6 \%$ & $29 \%$ & 117 & 80 & $60 \%$ & $100 \%$ & $0 \%$ & $100 \%$ & 5 & 5 \\
\hline Day 8 & \multirow{3}{*}{ nd } & - & & - & \multirow{3}{*}{$40 \%$} & - & \multirow{3}{*}{$0 \%$} & - & & - \\
\hline Day 10 & & - & nd & - & & - & & - & \multirow[t]{2}{*}{5} & - \\
\hline Day 13 & & - & & - & & - & & - & & - \\
\hline Day 15 & $0 \%$ & - & 14 & - & $40 \%$ & - & $0 \%$ & - & 5 & - \\
\hline
\end{tabular}

oysters in these $22-23^{\circ} \mathrm{C}$ sets exhibited nuclear alterations (Fig. 9) similar to the nuclear lesions observed in the larvae reared at $25-26^{\circ} \mathrm{C}$ (Fig. 6). These nuclear alterations were characterized by condensed nuclei appearing very electron dense, but with some round, electron-lucent areas (Fig. 9). However, in no set of larvae held at $22-23^{\circ} \mathrm{C}$ were these abnormalities associated with the detection of herpes-like viral particles. Moreover, these nuclear alterations were not found in any larvae from Brest.

Comparing these results to survival rates (Fig. 2), herpes-like viral particles were found in those $25-26^{\circ} \mathrm{C}$ sets in which sudden high mortalities occurred, while nuclear alterations in $22-23^{\circ} \mathrm{C}$ sets were correlated with more progressive mortalities. Moreover, in the La Tremblade set reared at $25-26^{\circ} \mathrm{C}$, larvae exhibiting nuclear lesions observed by light microscopy were $0 \%$ on Day $6,49 \%$ on Day 8 and $100 \%$ on Day 13 (Table 1 ). $100 \%$ mortality in this group also occurred on Day 13 , while the presence of viral particles detected by transmission electron microscopy was found in $0 \%$ of the larvae on Day 6 and $100 \%$ on Day 8. For larvae from
Marennes at $25-26^{\circ} \mathrm{C}, 29 \%$ exhibited nuclear lesions on Day 6, while viral particles were found in $100 \%$ by transmission electron microscopy on the same day. In the group of larvae from Marennes, $100 \%$ mortality occurred on Day 8 , but no analysis by light or transmission electron microscopy could be performed since all larval shells were empty. For larvae from Arcachon at $25-26^{\circ} \mathrm{C}$ on Day 6, $100 \%$ exhibited nuclear lesions under light microscopy, $100 \%$ contained viral particles and $100 \%$ mortality occurred.

\section{DISCUSSION}

In the present study, effects of temperature were investigated by comparing survival and growth rates of Crassostrea gigas spawns reared at either $22-23^{\circ} \mathrm{C}$ or $25-26^{\circ} \mathrm{C}$. These results were related to the histological and ultrastructural examination of oyster larvae. Although samples of all sets of oyster larvae were fixed each day, we performed transmission electron microscopy only for samples corresponding to the 


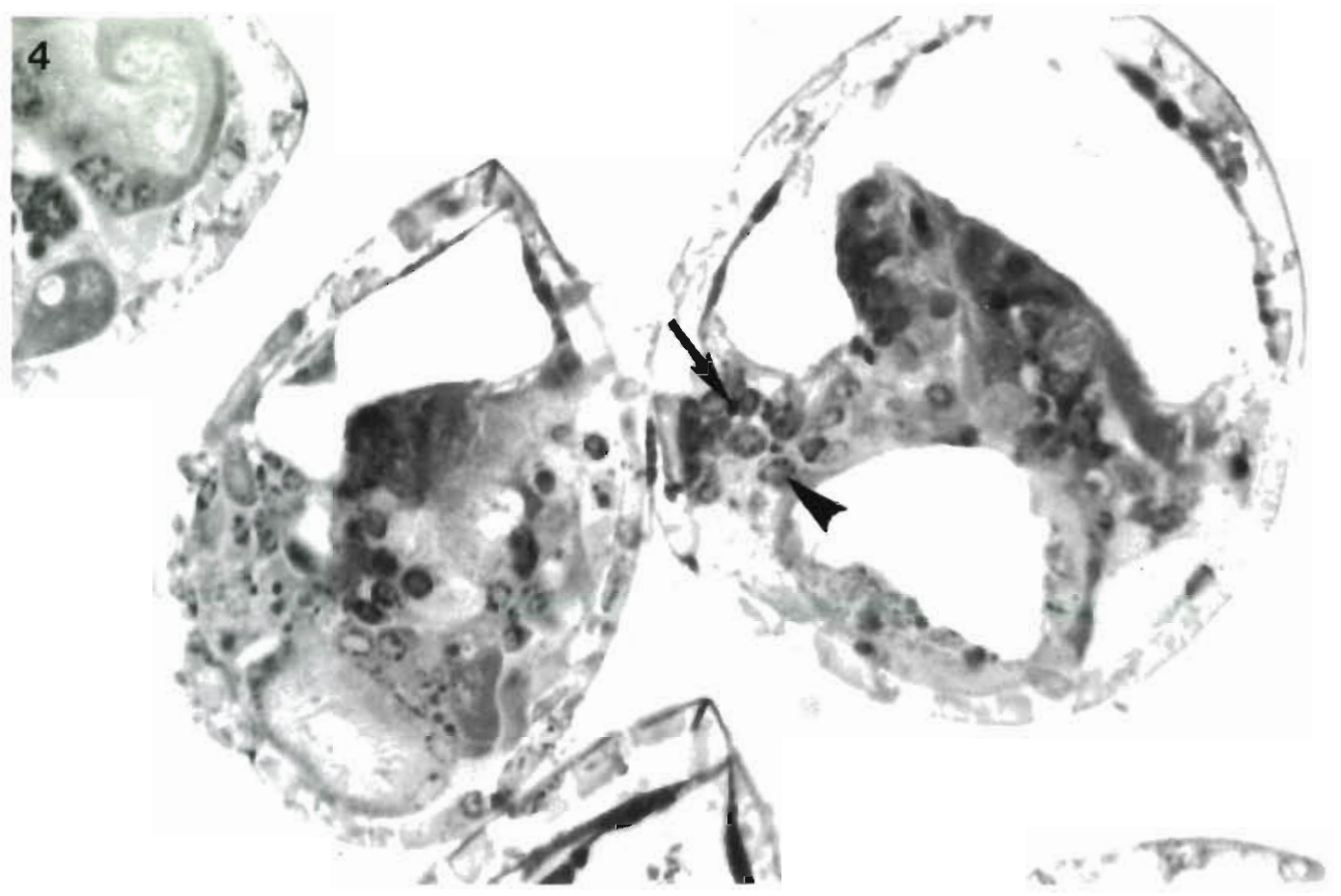

Fig. 4. Crassostrea gigas. Toluidine-blue-stained semithin sections of Pacific oyster larvae. Larvae from parents originating from Arcachon, La Tremblade and Marennes held at $22-23^{\circ} \mathrm{C}$ or $25-26^{\circ} \mathrm{C}$ exhibited nuclear lesions. Arrow: condensed, hyperbasophilic nuclei. Arrowhead: enlarged nuclei presenting marginalisation of chromatin

development of mortalities. Although it was difficult to handle numerous samples using this method, this procedure enabled us to compare survival rates and observations of nuclear lesions and viral particles. Moreover, observation of later viral infection could not be performed as infected cells detach from the larvae, and the shells of the oyster larvae were empty a few days after the beginning of the infection.

Viruses related to the family Herpesviridae were previously described in Pacific oyster Crassostrea gigas larvae (Hine et al. 1992, Nicolas et al. 1992) and associated with high and sudden mortalities occurring early in oyster larvae development, usually between Days 6 and 8 post fertilization. But sometimes $100 \%$ larval mortalities associated with herpesvirus infection were observed as soon as Day 4 post fertilization ( $T$. Renault pers. comm.). These results point out the importance of checking survival rates of oyster larvae daily. Moreover, we tried to relate these survival rates with the presence of lesions associated with herpesvirus infection. Indeed, Nicolas et al. (1992) and Renault et al. (1994b) previously described the main histological changes in herpesvirus-infected larvae as abnormal basophily of connective cells, presence of enlarged nuclei that show abnormal shape and chromatin pattern and condensed hyperbasophilic nuclei. These authors also reported herpesvirus particles in association with these cellular alterations. Moreover, viral particles were often observed in enlarged nuclei, but only occasionaly in condensed nuclei (Renault et al. 1994b). For diagnostic purposes, the nuclear alterations, particularly marginated chromatin in hypertrophied nuclei, can be detected by either light or transmisson electron microscopy. Although transmission electron microscopy is actually the most reliable method for diagnosis of marine mollusc viruses, light microscopy allows one to look at a greater number of specimens in each sample (Table 1) and thus increases the likelihood of detecting those specimens potentially carrying the infection.

The demonstration of herpesvirus pathogenicity was performed by inoculating axenic oyster larvae with viral suspensions (Le Deuff et al. 1994). Sudden and high mortalities accurred within 2 to $4 \mathrm{~d}$ post inoculation. Viral particles were observed by transmission electron microscopy in moribund axenic oyster larvae, and histological and ultrastructural changes in these larvae were identical to the lesions described in naturally infected oysters.

In the present study, mortalities in sets of oyster larvae from Marennes, La Tremblade and Arcachon held at $25-26^{\circ} \mathrm{C}$ occurred suddenly compared to mortalities in sets held at $22-23^{\circ} \mathrm{C}$. The mortalities of oyster larvae held at $25-26^{\circ} \mathrm{C}$ reached $100 \%$ on Days 6 to 13 of culture, which was in accordance with previous reports of herpesvirus infections (Hine et al. 1992, 

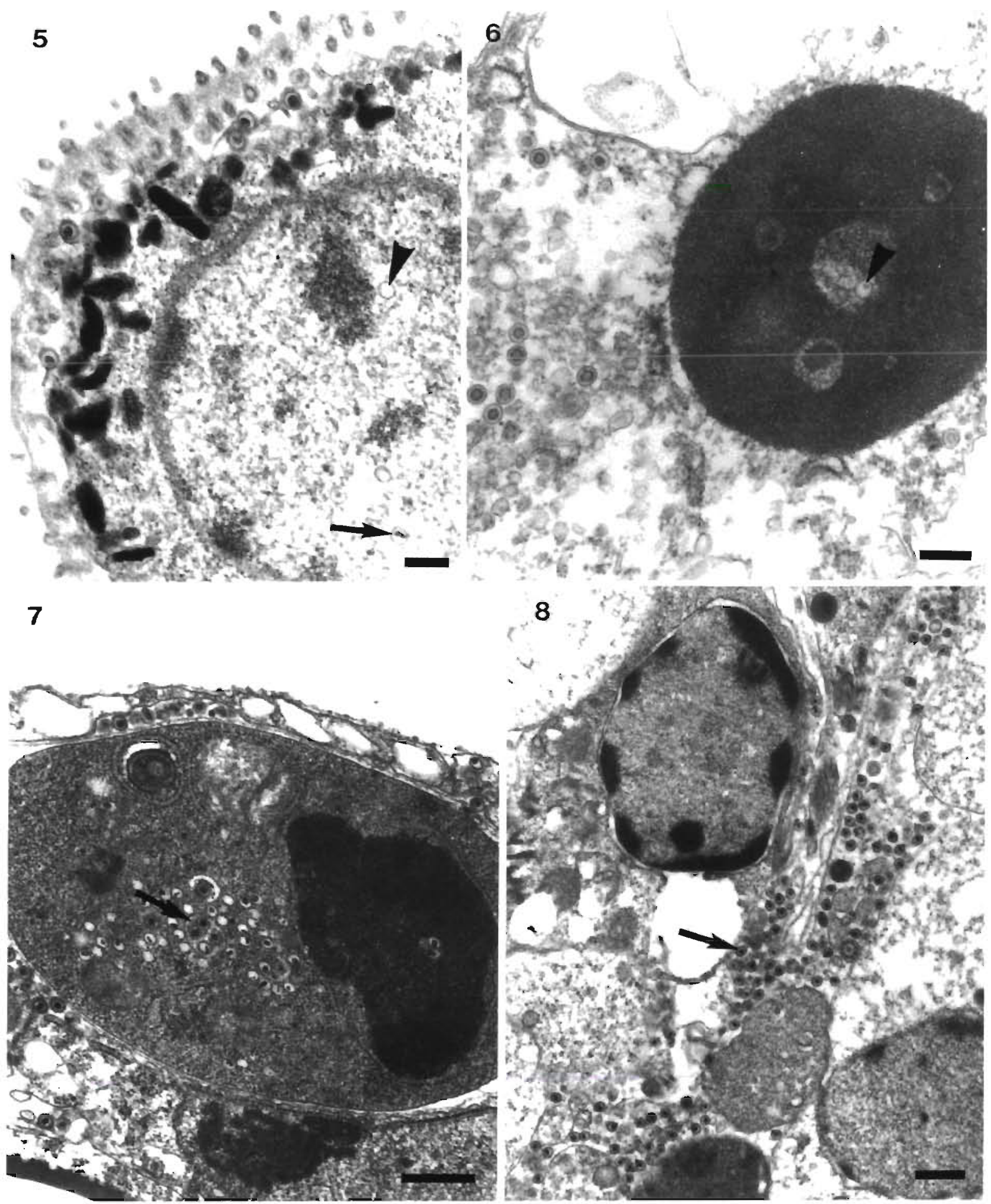

Figs. 5 to 8. Crassostrea gigas. Transmission electron micrographs of herpes-like virus infected cells of Pacific oyster larvae held at $25-26^{\circ} \mathrm{C}$. Figs. $5 \& 6$. Intranuclear spherical or polygonal viral particles. Some particles appeared empty (arrowheads) and others contained an electron dense core (arrow). Scale bar $=200 \mathrm{~nm}$. Fig. 7 . Enveloped viruses (arrow) within cytoplasmic vesicles in an infected cell of a Pacific oyster larva. Scale bar $=500 \mathrm{~nm}$. Fig. 8. Enveloped herpes-like viral particles (arrow) found in extracellular spaces. Scale bar $=500 \mathrm{~nm}$ 
Fig. 9. Crassostrea gigas. Transmission electron micrograph of nuclear alterations observed in Pacific oyster larvae held at $22-23^{\circ} \mathrm{C}$. The nucleus appeared very electron dense, but with some electron-lucent areas. Scale bar $=200 \mathrm{~nm}$

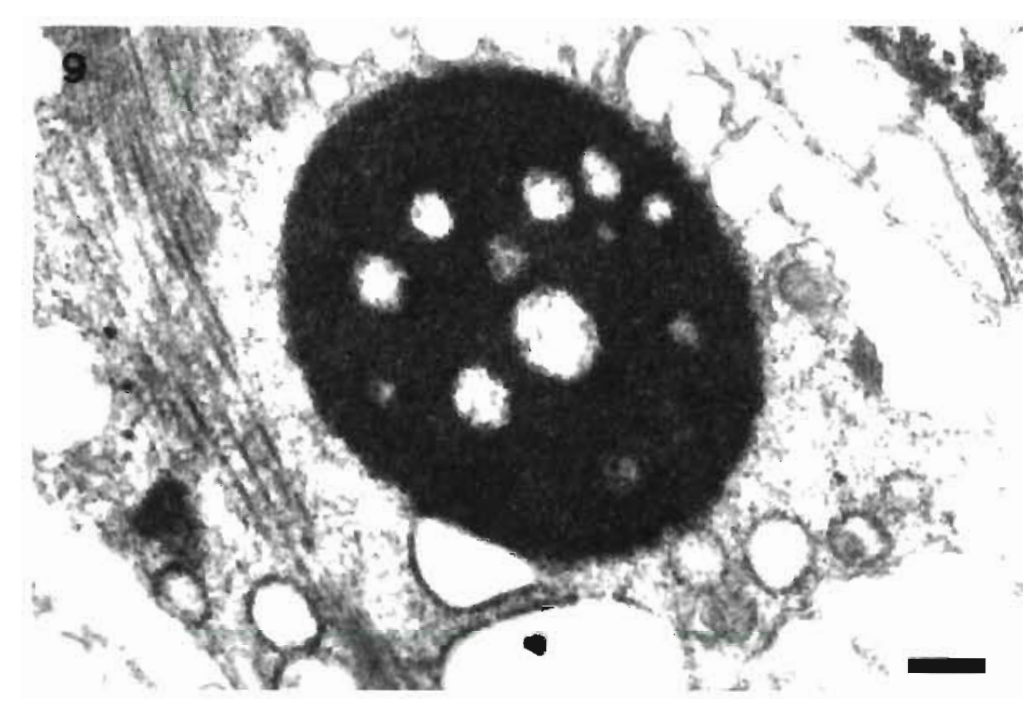

Nicolas et al. 1992) and with results concerning experimentally infected larvae (Le Deuff et al. 1994) which suggest that this virus may have a short multiplication cycle and may spread quickly.

Best survival rates were obtained for groups of larvae from Brest. Survival levels on Day 15 of culture were higher for larvae held at $25-26^{\circ} \mathrm{C}(44.4 \%)$ than for larvae held at $22-23^{\circ} \mathrm{C}(17.4 \%)$. These results could be expected since high temperatures $\left(25-26^{\circ} \mathrm{C}\right)$, in the absence of pathological problems, are optimal for the development and survival of Crassostrea gigas larvae. In optimal conditions $\left(25-26^{\circ} \mathrm{C}\right)$, a survival rate of 40 to $50 \%$ is expected on Day 15 of culture, while it decreases to $10-20 \%$ at $22-23^{\circ} \mathrm{C}$ for spawns obtained by gonad strip dissection method (A. Gérard pers. comm.). Moreover, growth rates could not be related to the development of herpesvirus infection, since no noticeable difference was observed between groups of oyster larvae held at the same temperature. But, it can be expected that at low temperatures $\left(22-23^{\circ} \mathrm{C}\right)$ larval growth is slower than at high temperatures $\left(25-26^{\circ} \mathrm{C}\right)$ and, considering the respective breeding temperatures, larval growth rates obtained here were standard (A. Gérard pers comm.).

When comparing survival rates, we noted that herpes-like viral particles were found in groups of oyster larvae in which high and sudden mortalities occurred. A further comparison of results from light and transmission electron microscope analyses in conjunction with the time course of survival at $25-26^{\circ} \mathrm{C}$ may also shed light on the rate of viral development in larvae. This is well illustrated with oyster larvae from La Tremblade reared at $25-26^{\circ} \mathrm{C}$. In this group, viral particles could be observed in $100 \%$ of the larvae as early as Day 8, while light microscopy revealed nuclear lesions in only $49 \%$. This difference is thought to reflect that weak viral infection could not be detected easily by light microscopy. On Day 13, at a further stage of viral infection, $100 \%$ of the larvae examined by light microscopy were found to exhibit nuclear lesions; these larvae were indeed heavily infected and larval mortality reached $100 \%$. Observations made on groups of larvae from Marennes and Arcachon reared at $25-26^{\circ} \mathrm{C}$ are in agreement with this hypothesis.

In this study, viral particles were observed only in larvae held at $25-26^{\circ} \mathrm{C}$. A similar feature was reported by Farley (1972) when adult Crassostrea virginica suffered a high mortality $(52 \%)$ associated with herpes-like viral infection when held at 28 to $30^{\circ} \mathrm{C}$, versus control oysters reared at 12 to $18^{\circ} \mathrm{C}(18 \%$ mortality $)$ in which no viral infection was found. However, nuclear alterations were histologically observed in this study in oysters reared at $22-23^{\circ} \mathrm{C}$, although not associated with the presence of viral particles at the ultrastructural level. Moreover, no other pathogen which could provoke such lesions was observed. These nuclear abnormalities could result either from a low productive viral cycle in which viral particles are very rare, or from a nonproductive state, in which viral particles are not produced. In this last case, 2 hypotheses may be developed. First, these nuclear alterations could result from a viral protein expression associated with a true latent viral phase (Meyers 1979, Garcia-Blanco \& Cullen 1991). Second, nuclear alterations could result from an abortive viral cycle, in which only some early phases of the viral cycle are achieved, with synthesis of structural or functional proteins and eventually viral DNA replication, but without any production of virions (Girard \& Hirth 1989). Consequently, structural aspects of the infected cell nuclei would change. It is important to note that, for viruses belonging to the Herpesviridae, 
a low productive or an abortive viral cycle is generally associated with a further switch of the virus to a latent state (Girard \& Hirth 1989).

For these reasons, larval rearing at $22-23^{\circ} \mathrm{C}$ is potentially hazardous because, although acute infection is avoided, limiting larval mortalities, latent, asymptomatic carrier larvae could be produced and the virus disseminated. In other words, larvae held at low temperatures $\left(22-23^{\circ} \mathrm{C}\right)$ which exhibit no evidence of viral particles under transmission electron microscopy could nonetheless be infected by the herpes-like virus; these carriers may represent reservoirs of the virus and could transmit this agent. Oysters produced by such larval breedings could also be susceptible to a switch from a latent to a productive infection at a later time.

In conclusion, it seems that both temperature and origin of parents, when breeding temperatures are the same, apparently influence expression of herpes-like virus in Crassostrea gigas larvae. Higher temperatures promote early production of viral particles in association with high mortalities. The result is a fast spread of the disease to the whole brood and high sudden mortalities. Larvae originating from some oyster broodstocks, particularly from Brest, grew well at both rearing temperatures. Since neither herpes-like virus nor nuclear alterations were detected in these larvae, parental origin might be important in relation to appearance of the disease among larvae. As all the larval breedings were performed at the same time and in the same conditions at both temperatures, this result suggests that one mode of transmission of this virus could be vertical, from parent to larvae. Moreover, with the gonad strip dissection procedure, this possible vertical transmission could occur either via the gamete cells or via the many extraneous, non-gamete cells.

Although no mortalities occurred among the different broodstocks of Crassostrea gigas used in this study, a further hypothesis is that the virus is present in a latent phase in some of the parents and is activated by stress in these hosts (Garcia-Blanco \& Cullen 1991), such as a modification of rearing temperature. Adults are usually held at $22^{\circ} \mathrm{C}$, generally warmer than in the natural environment, to accelerate the gonadal maturation process. Other stressors include manipulation or transport of animals, crowding or a modification of feeding. The virus induced by this stress would be transmitted to larvae. Consequently, in Iarvae reared at high temperatures $\left(25-26^{\circ} \mathrm{C}\right)$, the viral productive cycle would be faster and the virus would spread quickly to the whole brood, leading to high and sudden mortalities of larvae. In contrast, in larvae reared at lower temperatures $\left(22-23^{\circ} \mathrm{C}\right)$ and presenting nuclear alterations, the viral replication may remain in an abortive viral cycle (Girard \& Hirth 1989).
Our plans for testing this last hypothesis will probably indicate the mechanisms of transmission of the disease and its relations to temperature or other stressors. We expect to establish a breeding procedure that could avoid the production and dissemination of larvae carrying the virus and which might be susceptible to developing the disease in a later spat stage or transmitting the herpes-like virus to their progeny. Our future plans also include the purification of herpes-like virus of Crassostrea gigas and further development of diagnostic methods based on the use of nucleic acid probes or antibodies specific for this virus in order to study the possibility of associating the detection of nuclear abnormalities with the presence of viral DNA and/or viral proteins. Establishment of such diagnostic mothods would cnable not only epidemiological study and survey of the disease, but also verification of the hypotheses developed in this study.

Acknowledgements. This work was supported by the Conseil Général de la Charente Maritime. Dr S. K. Allen (Rutgers University, USA) is acknowledged for his comments and corrections on this paper.

\section{LITERATURE CITED}

Comps M, Bonami JR (1977) Infection virale associée à des mortalités chez l'huitre Crassostrea angulata Th. C R Acad Sci D 285:1139-1140

Comps M, Bonami JR, Vago C, Campillo A (1976) Une virose de l'huître portugaise (Crassostrea angulata). C R Hebd Séances Acad Sci D 282:1991-1993

Comps M, Cochennec N (1993) A herpes-like virus from the European oyster Ostrea edulis L. J Invertebr Pathol 62(2):201-203

Comps M, Duthoit JL (1976) Infection virale associée à la 'maladie des branchies' de l'huitre portugaise Crassostrea angulata Lmk. C R Hebd Séances Acad Sci D 283: $1595-1596$

Elston RA (1979) Viruslike particles associated with lesions in larval Pacific oysters (Crassostrea gigas). J Invertebr Pathol 33:71-74

Elston RA, Wilkinson MT (1985) Pathology, management and diagnosis of oyster velar virus disease (OVVD). Aquaculture 48:189-210

FAO (1989) FAO Fish Circ 815, rev 1. Food and Agriculture Organization, Rome

Farley CA (1972) Oyster herpes-type virus. Science 178: $759-760$

Farley CA (1976) Ultrastructural observations on epizootic neoplasia and lytic virus infection in bivalve mollusks. Prog exp Tumor Res 20:283-294

Farley CA (1978) Viruses and virus-like lesions in marine mollusks. Mar Fish Rev 40(10):18-20

Garcia-Blanco MA, Cullen BR (1991) Molecular basis of latency in pathogenic human viruses. Science 254:815-820

Girard $M$, Hirth L (1989) Différents types d'interactions virus-cellule. In: Doin (ed) Virologie moléculaire, Chap 5, Interactions virus-cellules. Flammarion et Cie, Paris, p 199-207 
Hine PM, Wesney B, Hay B (1992) Herpesviruses associated with mortalities among hatchery-reared larval Pacific oysters Crassostrea gigas. Dis aquat Org 12:135-142

Le Deuff RM, Nicolas JL, Renault T, Cochennec N (1994) Experimental transmission of herpes-like virus to axenic larvae of Pacific oyster, Crassostrea gigas. Bull Eur Ass Fish Pathol 14(2):69-72

Meyers TR (1979) A reo-like virus isolated from juvenile american oysters (Crassostrea virginica). J gen Virol 46: $203-212$

Responsible Subject Editor: A. K. Sparks, Seattle, Washington, USA
Nicolas JL, Comps M, Cochennec N (1992) Herpes-like virus infecting Pacific oyster larvae, Crassostrea gigas. Bull Eur Ass Fish Pathol 12(1):11-13

Renault T, Cochennec N, Le Deuff RM, Chollet B (1994a) Herpes-like virus infecting Japanese oyster (Crassostrea gigas) spat. Bull Eur Ass Fish Pathol 14(2):64-66

Renault T, Le Deuff R-M. Cochennec N, Maffart P (1994b) Herpesviruses associated with mortalities among Pacific oyster, Crassostrea gigas, in France - comparative study. Revue Méd Vét 145(10):735-742

Manuscript first received: August 29, 1994

Revised version accepted: August 11, 1995 